\title{
Contrasted growth response of hybrid larch (Larix $\times$ marschlinsii), jack pine (Pinus banksiana) and white spruce (Picea glauca) to wood ash application in northwestern Quebec, Canada
}

\author{
Nicolas Bélanger ${ }^{(1)}$, \\ Gustavo Palma Ponce ${ }^{(2)}$, \\ Suzanne Brais ${ }^{(2)}$
}

(1) Département Science et Technologie, Université TÉLUQ, 5800, rue Saint-Denis, Bureau 1105, Montréal, Québec H2S 3L5 (Canada); (2) Institut de Recherche sur les Forêts, Université du Québec en Abitibi Témiscamingue, 445 Blv. Université, RouynNoranda, Quebec J9X 5E4 (Canada)

\section{@ Nicolas Bélanger}

(nicolas.belanger@teluq.ca)

Received: Jul 21, 2020 - Accepted: Jan 29, 2021

Citation: Bélanger N, Palma Ponce G, Brais S (2021). Contrasted growth response of hybrid larch (Larix $\times$ marschlinsii), jack pine (Pinus banksiana) and white spruce (Picea glauca) to wood ash application in northwestern Quebec, Canada. iForest 14: 155-165. - doi: 10.3832/ifor3597-014 [online 2021-04-06]

Communicated by: Gianluca Piovesan

The use of wood ash as a soil amendment in afforestation and reforestation efforts is increasing. While most studies suggest benefits or neutral results on tree growth and survival, a few studies indicate adverse effects. Hybrid larch, jack pine and white spruce were studied at three northwestern Quebec plantation sites after they received wood ash at two application rates. Soil chemical properties, foliar nutrients and seedling growth and mortality were monitored over a period of eight years. The response of soil to ash application was mostly observed in the forest floor and was more pronounced in year 3 than year 8, likely due to the acidifying nature of the boreal soils studied. Jack pine growth increased linearly with wood ash application rates, white spruce growth showed an inconsistent and delayed positive response under the higher application rate, and hybrid larch growth and survival were either increased or decreased under the lower application rate depending of site but decreased at all sites under the higher application rate. The divergence in growth response between tree species underlines a trade-off between species with rapid acquisition of resources (e.g., pine, larch) to species that use more conservative strategies and store nutrients in their tissues for longer periods (e.g., spruce). In the case of hybrid larch, it accumulated larger amounts of $\mathrm{Mn}$ in its needles under the higher application rate and thus, the high bioavailability of $\mathrm{Mn}$ appears to have been detrimental to its survival and growth. Its higher sensitivity to $\mathrm{Mn}$ addition from ash is likely due to its highly acquisitive (nutrients) nature compared to other coniferous species as well as the initial levels of available $\mathrm{Mn}$ levels in the soil. The contrasted growth responses reported here under similar growing conditions highlight the importance of identifying suitable species, sites and application rates to maximize the benefits of wood ash amendments for future tree plantations in the boreal forest.

Keywords: Wood Ash, Fertilization, Boreal Forest, Soil Properties, Foliar Nutrition, Tree Growth

\section{Introduction}

Wood ash used as a soil amendment for afforestation or reforestation is common in some European countries (Lundborg 1998). Application of wood ash generally leads to improved soil nutrient availability and tree growth (Augusto et al. 2008, Reid \& Watmough 2014, Emilson et al. 2020). Another incentive of applying ash in forests is the reduced landfill disposal costs for forest and bioenergy industries (Hannam et al. 2016). Wood ash composition depends on combustion conditions (e.g., fly, bottom, mixed, cyclone) and fuel type (e.g., wood, peat, bark, chips - Swedish University of Agricultural Sciences, http://woodash.slu.se/eng/). Ash is generally $\mathrm{Ca}-, \mathrm{Mg}-\mathrm{K}$ - and P-rich and $\mathrm{N}$-poor and it may contain relatively large amounts of micronutrients (e.g., $\mathrm{Mn}, \mathrm{Cu}$ and $\mathrm{Zn}$ ) and toxic metals (e.g., $\mathrm{Cd}$ and $\mathrm{Pb}$ ). Augusto et al. (2008) characterized the bioavailability of toxic metals in forest soils following ash application and concluded that their presence was limited to surficial soil horizons and was not likely problematic for tree growth. This is likely due to: (i) a decrease in the solubility of most toxic metals associated with the increase in soil $\mathrm{pH}$ following ash application; (ii) the high capacity of organic matter in the forest floor to bind toxic metals; and (iii) the direct negative impacts of toxic metals on microbial activity (e.g., fungi), which tends to slow the mobilization not only of nutrients but of toxic metals as well. However, there are some studies suggesting that ash application can lead to tree growth decline in both juvenile and adult plantations, and toxicities induced by high levels of micronutrients (e.g., $\mathrm{Mn}$ ), non-nutrient metals (e.g., Cd) or salinity are suspected as the causes (Staples \& Van Rees 2001, Brais et al. 2015, Bieser \& Thomas 2019). Such situations are more likely to occur at higher ash application rates and some tree species (e.g., Picea spp.) are possibly more susceptible to a toxic response (Brais et al. 2015, Emilson et al. 2020). A few studies also reported negative impacts of wood ash application on seedling survival rate (Staples \& Van Rees 2001, Mandre et al. 2004). 

cies to ash application are common and can be associated to delays for nutrients from the ash to transfer to and react with the soil and eventually be absorbed by tree roots (Reid \& Watmough 2014). In the short term, nutrients stored in tree seedlings at the nursery could mask the positive growth response to ash application (Timmer 1997). Nutrient reserves in seedlings could also alleviate toxicities induced by high levels of micronutrients such as Mn and non-nutrient metals such as $\mathrm{Cd}$, as seen for many plants species (Alam et al. 2007, Kashem \& Kawai 2007). Short-term tree responses to ash application may not reflect long-term responses (Reid \& Watmough 2014), which means that more longitudinal studies are required. The diversity in the direction, timing and magnitude of growth responses is prompting for new studies of various tree species growing on an array of soils (e.g., acid-base and $\mathrm{N}$ status) and receiving different ash treatments to set proper threshold application rates.

In Canada, wood ash is classified as a waste material and as such, application in forest settings is discouraged under most provincial regulations and policies (Hannam et al. 2016). Due to the challenges of obtaining regulatory approval for application of ash to soils, the majority of the ash produced annually in the country is landfilled. Yet, this practice is increasing in popularity in some Canadian provinces, such as Quebec and Alberta, but most ash is applied in an agricultural context. Application rates to agricultural soils are set based on wood ash and soil chemical compositions, namely the content of toxic metals in ash

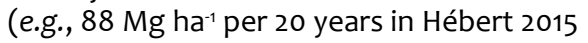
for Quebec), but these are well above the recommended rates for European forests (e.g., $6 \mathrm{Mg} \mathrm{ha}^{-1}$ per rotation in VarnagiryteKabašinskiene 2012 for Lithuania). AshNet, a network of Canadian government, academic and industry researchers, is aiming to study the potential benefits of wood ash on tree growth and come up with recommendations in regard to application rates
Lags in the growth response of tree spe-

for Canadian provinces and territories (Emilson et al. 2018). The work presented here is part of the AshNet initiative.

Our study reports mortality rates, growth, foliar nutrition and soil chemical composition of planted hybrid larch (Larix $\times$ marschlinsii), jack pine (Pinus banksiana) and white spruce (Picea glauca) seedlings over an eight-year period following ash application in the Quebec boreal forest. These species were selected because they are believed to have contrasted nutrient acquisition strategies. Hybrid larch is believed to be the most acquisitive, followed by jack pine and then white spruce (Gower \& Richards 1990, Diaz et al. 2004, Thiffault et al. 2006). In this respect, they are likely to respond differently to ash application. The primary objectives were to: (i) describe the growth response of these tree species to various ash application rates over time; and (ii) assess soil and foliar nutrients under the ash treatments as a means to explain growth responses. The hypothesis was that, as a whole, tree growth and survival would be improved by ash application and that the benefits would be greater under the higher application rate due to significantly improved soil nutrient availability, mostly in the forest floor, as well as for the more acquisitive tree species. However, there is also the possibility that some tree species could be sensitive to the high levels of some metals in the ash and in turn, tree growth and survival could be impaired if a certain threshold was exceeded.

\section{Materials and methods}

\section{Study sites and experimental design}

The study was conducted in the Abitibi region of northwestern Quebec, Canada, within the balsam fir (Abies balsamea) white birch (Betula papyrifera) bioclimatic domain (Saucier et al. 1998) of the boreal forest and within the Precambrian Shield. Two sites were selected: Pascalis $\left(48^{\circ} 12^{\prime} \mathrm{N}\right.$, $77^{\circ} 27^{\prime} \mathrm{W} ; 345 \mathrm{~m}$ a.s.l.) and Senneterre ( $48^{\circ}$ $24^{\prime} \mathrm{N}, 77^{\circ} 04^{\prime} \mathrm{W} ; 380 \mathrm{~m}$ a.s.l.). Climatic data are not available for these sites. Basic cli-

Tab. 1 - Forest floor and mineral soil (upper B horizon) chemical properties prior to wood ash application at the study sites and used to calculate the ash application rate needed to adjust the upper $\mathrm{B}$ mineral soil $\mathrm{pH}$ in water to 5.5. $\mathrm{pH}$ was measured in water (active acidity). pH buffer capacity was measured after adding a buffer solution (7.0) as an indication of the acidity reserve and the amount of lime required to neutralize it and to reach a target $\mathrm{pH}$ in water. Organic matter was measured by loss on ignition in a muffle furnace at $375{ }^{\circ} \mathrm{C}$ (McKeague 1978). It was not measured for the forest floor (n/a). CEC $\mathrm{e}_{\mathrm{e}}$ is effective cation exchange capacity and was calculated from exchangeable $\mathrm{Ca}, \mathrm{Mg}, \mathrm{K}, \mathrm{Na}$ and acidity after an extraction with $0.1 \mathrm{M} \mathrm{NH}_{4} \mathrm{Cl}$ (Bélanger et al. 2007). See Materials and Methods section for details on analyses.

\begin{tabular}{llcccc}
\hline Layer & Site & $\mathrm{pH}$ & $\begin{array}{c}\mathrm{pH} \text { buffer } \\
\text { capacity }\end{array}$ & $\begin{array}{c}\text { Organic } \\
\text { matter (\%) }\end{array}$ & $\begin{array}{c}\mathrm{CEC}_{\mathrm{e}} \\
\left(\mathbf{c m o l}_{\mathbf{~}} \mathbf{~ k g}^{-1}\right)\end{array}$ \\
\hline \multirow{2}{*}{ Forest floor } & Pascalis & 6.00 & 3.90 & $\mathrm{n} / \mathrm{a}$ & 15.1 \\
\cline { 2 - 6 } & Senneterre & 5.60 & 4.20 & $\mathrm{n} / \mathrm{a}$ & 18.4 \\
\multirow{2}{*}{ Mineral soil } & Pascalis & 4.82 & 6.35 & 2.38 & 1.05 \\
\cline { 2 - 6 } & Senneterre & 4.73 & 5.90 & 5.83 & 1.50 \\
\hline
\end{tabular}

matic variables were therefore simulated using the BioSIM model (Régnière 1996) for each year of the study period (20072014), and then computed into an average over the 8 years. The model uses elevation, latitude and longitude and multivariate regressions for extrapolating data from the nearest weather stations. It provides data that are not statistically different from measured data. At Pascalis, mean daily air temperatures in January and July were $15.5^{\circ} \mathrm{C}$ and $17.6{ }^{\circ} \mathrm{C}$, respectively, whereas mean annual precipitation was $918 \mathrm{~mm}$. At Senneterre, mean daily air temperatures were $-15.6{ }^{\circ} \mathrm{C}$ in January and $16.9{ }^{\circ} \mathrm{C}$ in July, while mean annual precipitation was 932 $\mathrm{mm}$. Of the total precipitation at both sites, $49 \%$ fell between May and September. Soils at both sites are Dystric Eluviated Brunisols developed from quaternary deposits (Expert Committee on Soil Survey 1998). The forest floor at the sites is a mor type (10-15 cm depth) originating from feathermoss. Field assessments suggest that the mineral soil (i.e., upper $\mathrm{B}$ horizon) at Pascalis and Senneterre have a loamy sand texture and a sandy loam texture, respectively. This is consistent with a slightly higher effective cation exchange capacity and acidity reserve of the mineral soil at Senneterre (Tab. 1). Organic matter levels in the upper $\mathrm{B}$ horizon are quite low. Using a correction of 0.583 (Expert Committee on Soil Survey 1998), they are equivalent to $1.39 \%$ and $3.40 \%$ of carbon in Pascalis and Senneterre, respectively,

The experimental design was comprised of three plantations/sites or experimental blocks (i.e., Pascalis 1, Pascalis 2 and Senneterre) varying from 30 to 40 ha in size which were former jack pine stands harvested in 2005. It was set as a randomized complete block design with three blocks (plantation/sites), three ash treatments $(3 x)$ and three species $(3 x)$ nested within each ash treatment. Again, the species were hybrid larch, jack pine and white spruce. Hybrid larch and jack pine were present at all sites $(3 \times)$, whereas white spruce was present at Pascalis 1 and Pascalis 2 only $(2 x)$.

The ash was loose non-stable fly ash (see Tab. 2 for physicochemical composition) originating from a wood residue thermal power plant, which mostly uses softwood bark residues from sawmills. Compared to the fly ash data $(n=189)$ compiled in the Wood Ash Database (http://woodash.slu.se /eng/stats.cfm), the fly ash in our study exhibits relatively low levels of toxic metals, except for Mn and Ba which are comparable to the average fly ash in the Wood Ash Database.

The ash treatments consisted in a control, a half load and a full load. The full load corresponded to an ash application rate to adjust the upper $\mathrm{B}$ mineral soil $\mathrm{pH}$ in water to 5.5. To determine this value, we first measured general soil properties of a few soil samples at each site, namely the acidity reserve ( $\mathrm{pH}$ buffer capacity) of the upper $\mathrm{B}$ 
horizon and $\mathrm{pH}$ in water (Tab. 1). Analytical methods are detailed in Tab. 1 or specified later in this section. Fine lime was considered to have an acid neutralizing capacity of $85 \%$, an efficiency of $88 \%$, and an effective neutralizing capacity (ENC) of $75 \%$ (CRAAQ 2013). Fine lime requirements were calculated on a hectare basis for 17 $\mathrm{cm}$ of soil and assuming a soil bulk density of $1320 \mathrm{~kg} \mathrm{~m}^{-3}$ (CRAAQ 2013). Chemical analyses at the power plant determined that the wood ash has an acid neutralizing capacity of $35 \%$, an efficiency of $100 \%$ and an ENC of $35 \%$. The very high fineness of grind explains the full efficiency of the wood ash. Thus, for a lime requirement of $6.7 \mathrm{dry} \mathrm{Mg}$ $\mathrm{ha}^{-1}$ to reach a soil pH in water of 5.5 at the Senneterre site, the equivalent wood ash requirement was calculated as: (6.7 dry $\mathrm{Mg}$ ha $^{-1}$ fine lime requirement $\times 75 \%$ ENC lime)/ (35\% ENC_wood ash) $=22 \mathrm{Mg} \mathrm{ha-1}$ of wood ash.

Because the wood ash is $65 \%$ dry matter and fine lime is close to $100 \%$ dry matter, this is equivalent to $14 \mathrm{Mg}$ ha $^{-1}$ of dry ash. The coarser texture and thus the lower reserve of acidity of the mineral soil at Pascalis (Tab. 1) explain the lower wood ash application rate needed to raise soil $\mathrm{pH}$ in water to 5.5. This was calculated as an equivalent of 5 dry $\mathrm{Mg} \mathrm{ha}^{-1}$ in Pascalis 1 and Pascalis 2. The treatment corresponding to the half load was thus 2.5 dry $\mathrm{Mg} \mathrm{ha}^{-1}$ in Pascalis 1 and Pascalis 2 and 7 dry $\mathrm{Mg} \mathrm{ha}^{-1}$ in Senneterre. The ash was applied in the fall of 2006 using a forest harvester equipped with a road sander. Following application, the sites were mechanically prepared with a TTS power disc trencher to incorporate the ash in the mineral soil. Sites were planted in late May to early June of 2007.

\section{Field measurements, sampling and laboratory analyses}

In the fall of 2007 (year 1), surviving seedlings were measured for diameter at breast height (DBH) and total height in two $10 \times$ $10 \mathrm{~m}$ sampling units within each block $\times$ ash treatment $\times$ species sub-plot of the experiment. Measurements were repeated in 2008, 2009 and 2014 (years 2, 3 and 8, respectively) in the same sampling units on surviving seedlings. Because sampling units contained 25 seedlings, it was possible to calculate a yearly mortality rate based on the number of measured seedlings. There was one exception for hybrid larch in 2009 when seedlings falling outside the sampling units were inadvertently measured to reach a total of 25 seedlings per sampling unit. Thus, a mortality rate could not be calculated in 2009 for hybrid larch.

In year 3, two seedlings per sampling unit were harvested after tree hardening (second week of October), and their total needle mass was air dried and ground for chemical analyses. Samples were digested in a $\mathrm{HSO}_{4}-\mathrm{H}_{2} \mathrm{O}_{2}$ mixture. Phosphorus, $\mathrm{K}, \mathrm{Ca}$ and $\mathrm{Mg}$ were measured by ICP mass spectrometry (Perkin-Elmer Optima ${ }^{\circledast} 4300 \mathrm{DV}$ ), while total $\mathrm{N}$ was measured using the Kjel- dahl method. Total needle mass and nutrient concentration allowed the measurement of needle nutrient content. Thus, the changes in needle mass and $\mathrm{N}, \mathrm{P}, \mathrm{K}, \mathrm{Ca}$ and $M g$ nutrient concentration and content under the half and full loads were measured relative to the control in year 3 . In the second week of October in year 8 , needles were sampled from a single branch of six seedlings per sampling unit and then air dried and ground. Considering the relatively high levels of $\mathrm{Mn}$ and $\mathrm{Ba}$ in ash (Tab. 2), these elements along with $\mathrm{N}, \mathrm{P}, \mathrm{K}, \mathrm{Ca}$ and $\mathrm{Mg}$ were analyzed on foliar samples collected at year 8 . The same analytical methods as in year 3 were used, except for a different ICP mass spectrometer (Varian ${ }^{\circledR}$ $820 \mathrm{MS}$, Agilent Technologies, CA, USA).

Soil samples were collected from the residual forest floor and the $0-15 \mathrm{~cm}$ mineral soil at opposite extremities of each sampling unit in 2009 and 2014. Forest floor and mineral soil samples were air-dried, sieved $(2 \mathrm{~mm})$ and analyzed for $\mathrm{pH}$ in 0.01 $\mathrm{M} \mathrm{CaCl}$ using 1:4 and 1:2 ratios, respectively. Exchangeable cations were extracted with $\mathrm{NH}_{4} \mathrm{Cl}-\mathrm{BaCl}_{2}$ (Amacher et al. 1990). Calcium, Mg, K and Na were analyzed by inductively coupled plasma atomic emission (ICP - Perkin-Elmer Optima ${ }^{\circledR} 4300$ DV), whereas exchangeable acidity was analyzed by titration (848 Titrino plus, Metrohm AG, Herisau, Switzerland). Effective cation exchange capacity $\left(\mathrm{CEC}_{\mathrm{e}}\right)$ was estimated by calculating the sum of base cations and exchangeable acidity (Acidity e. $^{2}$. Base saturation was defined as the sum of $\mathrm{Ca}, \mathrm{Mg}, \mathrm{K}$ and $\mathrm{Na}$ divided by $\mathrm{CEC}_{\mathrm{e}}$. Available $P$ was assessed by means of a Bray 2 extraction in 2009 and a Mehlich-3 extraction in 2014 (Ziadi \& Sen Tran 2008). In both cases, extractions were analysed by ICP. Finally, soil samples were ground to pass through a $250 \mu \mathrm{m}$ mesh and analyzed for Kjeldahl $\mathrm{N}$ after a digestion in a $\mathrm{HSO}_{4}-\mathrm{H}_{2} \mathrm{O}_{2}$ mixture.

Because of the high levels of $\mathrm{Mn}$ in the fly ash (Tab. 2), a sequential extraction for $\mathrm{Mn}$ was conducted on a subset of forest floor and mineral soil samples collected under hybrid larch in year 8 (i.e., 3 sites $\times 3$ treatments $\times 2$ soil types $\times 1$ bulk sample from the two replication plots per site/treatment) according to the method of Warden \& Reisenauer (1991). This procedure separates $\mathrm{Mn}$ into four forms, i.e., readily soluble $\mathrm{Mn}\left(0.05 \mathrm{M} \mathrm{Ca}\left(\mathrm{NO}_{3}\right)_{2}\right)$, weakly adsorbed $\mathrm{Mn}\left(0.025 \mathrm{M}\right.$ CaDTPA in $\left.0.025 \mathrm{M} \mathrm{Na}_{2} \mathrm{~B}_{4} \mathrm{O}_{7}\right)$, specifically adsorbed $\mathrm{Mn}\left(0.05 \mathrm{M} \mathrm{Cu}\left(\mathrm{CO}_{3}\right)_{2}\right.$ in $\left.0.05 \mathrm{M} \mathrm{Ca}\left(\mathrm{NO}_{3}\right)_{2}\right)$, and oxide- $\mathrm{Mn}(0.1 \mathrm{M}$ $\mathrm{NH}_{2}-\mathrm{OH}-\mathrm{HCl}$ in $0.01 \mathrm{M} \mathrm{HNO}_{3}$ ). This is the sequence for carbonate-free soils (the $1.6 \mathrm{M}$ $\mathrm{HNO}_{3}$ extraction was omitted which is for carbonate-bound $\mathrm{Mn}$ ). The fly ash also had relatively high levels of $\mathrm{Ba}$ (Tab. 2). Thus, all forest floor samples collected in year 8 were also extracted with $0.1 \mathrm{M} \mathrm{NH}_{4} \mathrm{Cl}$ (Bélanger et al. 2007) instead of $\mathrm{NH}_{4} \mathrm{Cl}-\mathrm{BaCl}_{2}$ in order to analyze $\mathrm{Ba}$ (and $\mathrm{Mn}$ ) by ICP mass spectrometry (Varian 820MS).
Tab. 2 - Chemical properties of fly ash used in this study. Macro- and micro-elements were analyzed by ICP (PerkinElmer Optima 4300DV) from $\mathrm{HNO}_{3}$ or $\mathrm{HNO}_{3}-\mathrm{HCl}$ digestions, or by $\mathrm{x}$-ray fluorescence spectroscopy (Bruker S8 Tiger).

\begin{tabular}{|c|c|c|}
\hline $\begin{array}{l}\text { Proper- } \\
\text { ties }\end{array}$ & Variable & Value \\
\hline \multirow{3}{*}{ 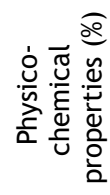 } & $\begin{array}{l}\text { Calcium carbonate } \\
\text { equivalent }\end{array}$ & 31 \\
\hline & $\begin{array}{l}\text { Fineness } \\
\text { (particles < 2mm) }\end{array}$ & 92 \\
\hline & Organic matter & 22 \\
\hline \multirow{6}{*}{ 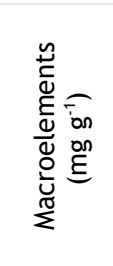 } & Calcium & 67 \\
\hline & Magnesium & 4 \\
\hline & Nitrogen & $<1$ \\
\hline & Phosphorus & 1 \\
\hline & Potassium & 9 \\
\hline & Sodium & 2 \\
\hline \multirow{16}{*}{ 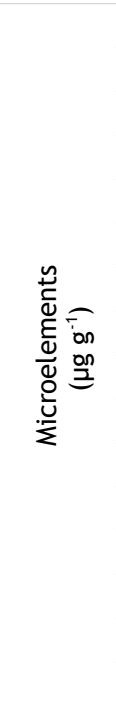 } & Arsenic & 2 \\
\hline & Bore & 62 \\
\hline & Barium & 1516 \\
\hline & Cadmium & 3 \\
\hline & Chromium & 11 \\
\hline & Cobalt & 10 \\
\hline & Copper & 20 \\
\hline & Iron & 1216 \\
\hline & Lead & 10 \\
\hline & Manganese & 7350 \\
\hline & Mercury & 0 \\
\hline & Molybdenum & 4 \\
\hline & Nickel & 12 \\
\hline & Rubidium & 90 \\
\hline & Strontium & 582 \\
\hline & Zinc & 286 \\
\hline
\end{tabular}

\section{Statistical analyses}

Descriptive statistics were conducted to calculate annual means and standard deviations of mortality rate, diameter, total height and foliar nutrients and $\mathrm{Ba}$ by ash treatments and tree species. For soil chemical variables, annual means and standard deviations were calculated for each treatment without distinguishing between tree species. Two-way ANOVAs were conducted on the different variables measured to test whether there was a significant interaction term between the two factors (i.e., treatments and sites). This test was selected over a mixed effect model because the sites were not intentionally selected to cover specific characteristics. ANOVAs were conducted by species on mortality rate, diameter, total height and foliar nutrients and $\mathrm{Ba}$ to test whether there is a significant interaction term between treatments and sites. ANOVAs were conducted similarly on soil variables without distinguishing between tree species. In all tests, sampled years were treated separately. No statistical test was conducted on sequential extraction $\mathrm{Mn}$ soil data to compare ash 
Fig. 1 - Hybrid larch (a), jack pine (b) and white spruce (c) mortality rates under the ash treatments in years $1,2,3$ and 8 . Means with standard deviations are presented. A significant interaction term (treatment $\times$ site) is represented by the * symbol. In such cases, treatment differences between site were detected using simple main effects testing and for concision, outcomes are summarized in writing in the results section.
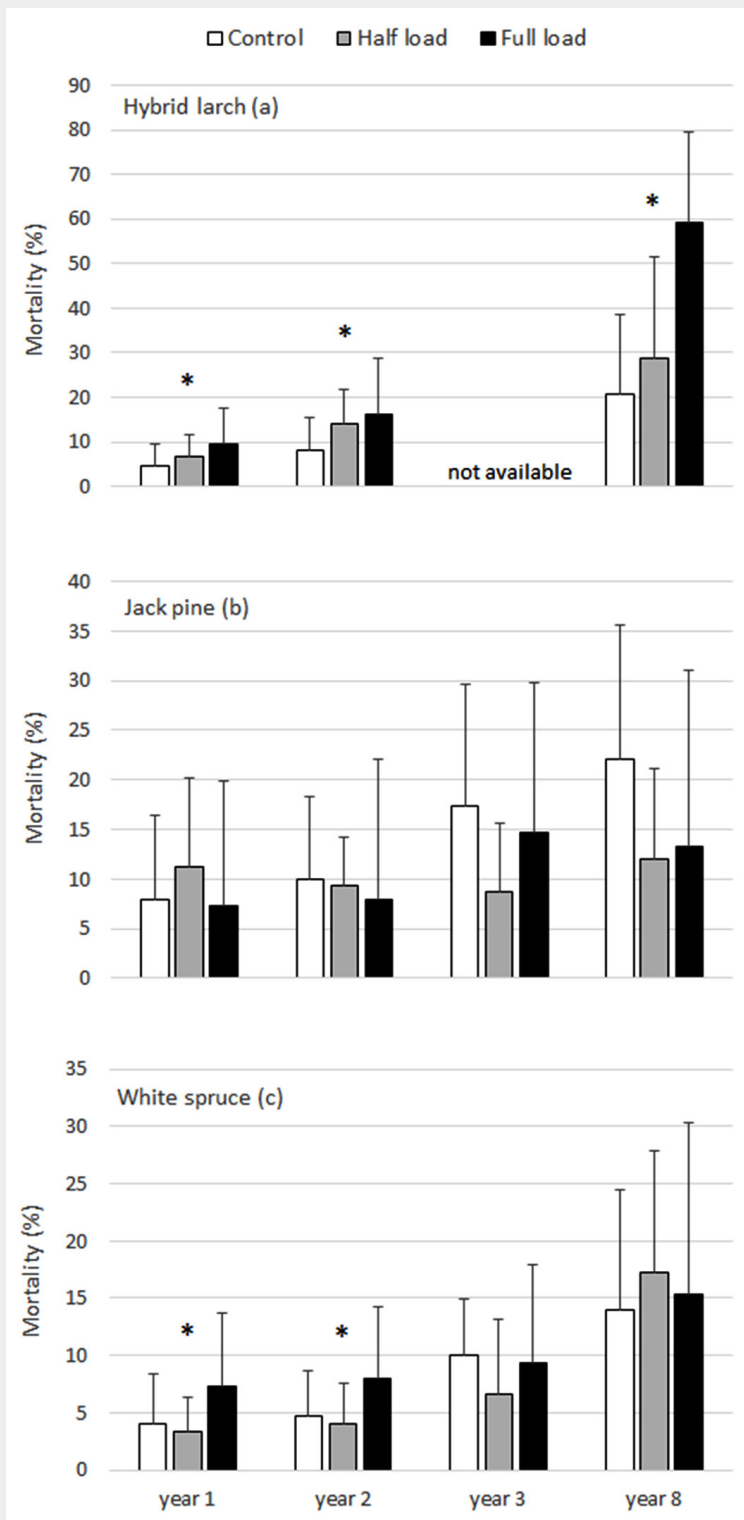

treatments under hybrid larch considering that only one sample per treatment per site was analyzed. When an interaction term was significant, simple main effects testing was conducted to characterize treatment (ash) effects within each site. In these cases, significant results were sum marized in writing in the next section - for the sake of concision, they were not presented graphically. If there was no significant interaction and a significant treatment effect was detected, a post hoc comparison was conducted using the Tukey's honest significant difference (HSD) test. The assumption of normality of residuals for the ANOVAs was met - data were transformed for only a few tests to meet this assumption. However, transformation of growth and foliar variables occasionally failed to homogenize variances between groups and thus, the assumption of homogeneity of variances could not be met for all tests. To avoid introducing an error in the test, a significant treatment effect on mortality rate, diameter, total height and foliar nutrients and $\mathrm{Ba}$ was accepted at $\mathrm{P}<0.02$ when the assumption of homogeneity of variance was not met. Otherwise, the significance level for interactions and comparison of means was set at $P<0.05$. Finally, one-way ANOVAs were conducted to test for significant differences in mortality rate, diameter and height between tree species and treatments in year 8 , followed by post hoc comparisons using the Tukey's HSD test at $P<0.05$. All statistics were conducted using the SigmaStat module in SigmaPlot ${ }^{\circledast}$ v. 13.0 (Systat Software, Inc., San José, CA, USA).

\section{Results}

\section{Mortality rate, diameter and total height}

Mean mortality rate, diameter and height of hybrid larch in year 8 were respectively $20.7 \%, 49.1 \mathrm{~mm}$ and $144 \mathrm{~cm}$ under the control, $28.7 \%, 50.6 \mathrm{~mm}$ and $276 \mathrm{~cm}$ under the half load and $59.3 \%, 19.0 \mathrm{~mm}$ and $96.3 \mathrm{~cm}$ under the full load (Fig. 1a, Fig. 2a, Fig. 2d). The interaction term was significant for all of the tests regarding hybrid larch mortal- ity (years 1, 2 and 8 ) and the tests for diameter and total height in years 3 and 8 . This led to simple main effects testing of treatments within each site. A negative effect of the full load relative to the control was observed at all sites for these variables. However, differences in mortality and diameter were significant only at Pascalis 2 and Senneterre, whereas differences in total height were significant at all sites in year 8 and only at Pascalis 2 in year 3 (results not shown). Survival, diameter and total height under the half load were anywhere from increased to decreased relative to the control. Overall, (i) the half load in Pascalis 1 had significantly higher mortality and lower diameter and total height than the control - values under the half load reached similar values to those under the full load in year 8; (ii) the half load in Pascalis 2 had significantly lower mortality and higher total height than the control; and (iii) the half load in Senneterre had significantly higher mortality, diameter and total height than the control (results not shown). Hybrid larch growth data in year 2 suggest similar overall trends, but ANOVAs did not meet the condition of homogeneity of variance and the significance threshold of $P<0.02$.

Jack pine mean mortality rate, diameter and height in year 8 were respectively 22.0 $\%, 39.5 \mathrm{~mm}$ and $180 \mathrm{~cm}$ under the control, $12.0 \%, 49.9 \mathrm{~mm}$ and $256 \mathrm{~cm}$ under the half load and $13.3 \%, 59.5 \mathrm{~mm}$ and $303 \mathrm{~cm}$ under the full load (Fig. 1b, Fig. 2b, Fig. 2e). There was no difference in mortality rate between treatments, but there was a significant positive growth response of jack pine to the full load (Fig. 1b, Fig. 2b, Fig. 2e). Both diameter and total height under the full load were generally significantly higher than the control and half load starting in year 2 and continuing in year 8 . At year 8 , however, there was no significant difference in diameter between the half and full loads. A linear relationship between growth and ash application rates was apparent, but this could not be fully shown as the tests failed to statistically differentiate the half load from either the control or full load or both.

Mean mortality rate, diameter and height of white spruce in year 8 were respectively $14.0 \%, 16.8 \mathrm{~mm}$ and $58.9 \mathrm{~cm}$ under the control, $17.3 \%, 18.0 \mathrm{~mm}$ and $64.9 \mathrm{~cm}$ under the half load and 15.3\%, $22.1 \mathrm{~mm}$ and $93.5 \mathrm{~cm}$ under the full load (Fig. 1C, Fig. 2C, Fig. 2f). The interaction term was significant for tests regarding white spruce mortality in years 1 and 2 . Simple main effects testing of treatments within each site revealed a significantly higher mortality under the full load than the control and half load at Pascalis 1 only. The only indication of a significant change in white spruce growth due to ash treatments was with height in year 8 (Fig. 2c, Fig. 2f). Simple main effects testing revealed a significantly higher height under the full load than the control and half load at Pascalis 2 only. The pattern for diameter was similar to that of height, but the 
Fig. 2 - Hybrid larch (a,d), jack pine $(b, e)$ and white spruce $(c, f)$ diameter and total height response to ash treatments in years $1,2,3$ and 8 . Means with standard deviations are presented. Different letters represent generalized significant differences between treatments within sampled years that were detected using the Tukey's HSD test. A significant interaction term (treatment×site) is represented by the * symbol. In such cases, treatment differences between site were detected using simple main effects testing and for concision, outcomes are summarized in writing in the results section.
ANOVA did not meet the condition of homogeneity of variance nor the significance level of $P<0.02$.

Due to the high variability in the dataset, notably in jack pine data, mortality rate between species in year 8 was generally not significantly different, with the exception of mortality of hybrid larch under the full load which was significantly higher than jack pine and white spruce (results not shown). There was no statistical difference between hybrid larch diameter and height under the half load and jack pine diameter and height under the half and full loads in year 8 (results not shown), thus suggesting a similar growth potential of hybrid larch under appropriate ash application rates. However, diameter and height of hybrid larch under the full load and of white spruce under all treatments in year 8 were significantly lower than diameter and height of jack pine under all treatments (results not shown).

\section{Foliar nutrients and barium}

There were very few significant differences in foliar macronutrients between ash treatments, i.e., Ca of hybrid larch in year 3 , $\mathrm{N}$ of hybrid larch in year 8 and $\mathrm{K}$ of jack pine in year 8 (Fig. 3). Hybrid larch under the full load had significantly higher foliar $\mathrm{Ca}$ than the control, whereas it had significantly higher foliar $\mathrm{N}$ in the half load com- $\square$ Control $\quad$ G Half load $\quad$ Gull load

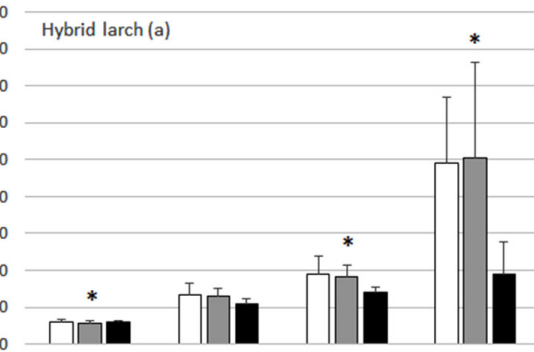

60

Jack pine (b)

50

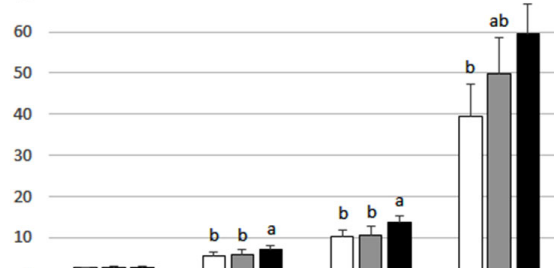

$\sqcap \curvearrowleft$

White spruce (c)

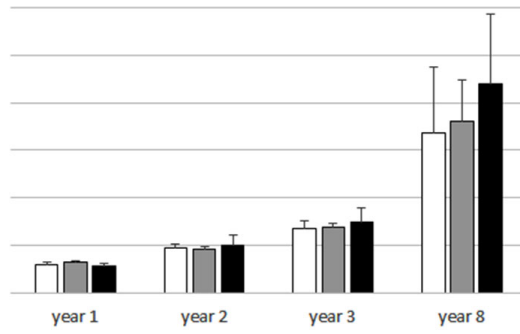

口Control $\square$ Half load $\quad$ Full load
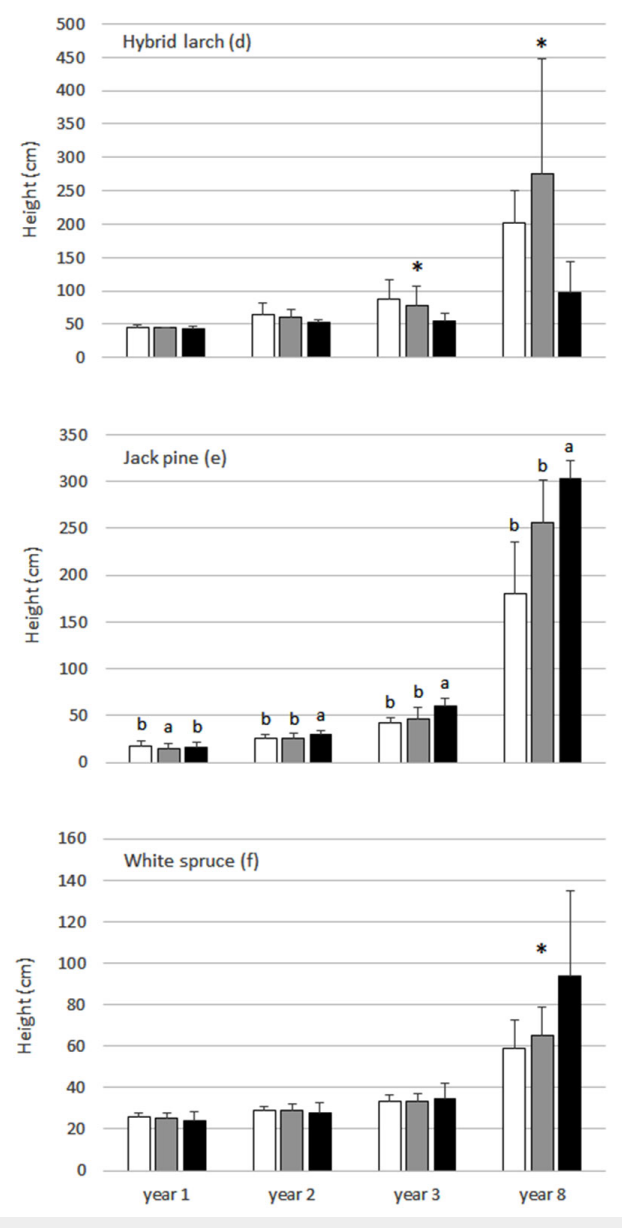

pared to the control. The interaction term for $\mathrm{K}$ in jack pine was significant, thus leading to simple main effects testing within each site. In Pascalis 1 and Senneterre, the full load had significantly higher foliar $\mathrm{K}$ than the control and half load (results not shown). In addition, the half load had significantly higher foliar $\mathrm{K}$ than the control and full load in Pascalis 2. Data also re-

Tab. 3 - Mean changes (\%) in needle mass and N, P, K, Ca and $\mathrm{Mg}$ concentrations and contents in year 3 under ash treatments relative to control.

\begin{tabular}{|c|c|c|c|c|c|c|}
\hline \multirow[b]{2}{*}{ Variable } & \multicolumn{2}{|c|}{ Hybrid larch } & \multicolumn{2}{|c|}{ Jack pine } & \multicolumn{2}{|c|}{ White spruce } \\
\hline & $\begin{array}{c}\text { Half load } \\
\text { vs } \\
\text { Control }\end{array}$ & $\begin{array}{c}\text { Full load } \\
\text { vs } \\
\text { Control }\end{array}$ & $\begin{array}{c}\text { Half load } \\
\text { vs } \\
\text { Control }\end{array}$ & $\begin{array}{c}\text { Full load } \\
\text { vs } \\
\text { Control }\end{array}$ & $\begin{array}{c}\text { Half load } \\
\text { vs } \\
\text { Control }\end{array}$ & $\begin{array}{c}\text { Full load } \\
\text { vs } \\
\text { Control }\end{array}$ \\
\hline Relative needle mass & -33.2 & -57.1 & +112 & +143 & -7.09 & -25.2 \\
\hline Relative $\mathrm{N}$ concentration & +4.37 & +2.11 & +8.49 & +27.1 & -27.8 & +16.8 \\
\hline Relative $\mathrm{N}$ content & -30.3 & -56.2 & +130 & +209 & -32.9 & -12.6 \\
\hline Relative P concentration & +20.8 & +20.2 & -9.99 & +0.10 & -25.3 & +5.29 \\
\hline Relative $\mathrm{P}$ content & -19.3 & -48.4 & +90.8 & +143.4 & -30.6 & -21.2 \\
\hline Relative $\mathrm{K}$ concentration & +1.19 & +0.50 & +8.41 & +31.4 & -23.2 & -7.27 \\
\hline Relative $\mathrm{K}$ content & -32.4 & -56.9 & +129.8 & +219 & -28.6 & -30.6 \\
\hline Relative Ca concentration & +39.7 & +52.1 & +46.7 & +62.2 & -8.61 & +29.5 \\
\hline Relative Ca content & -6.66 & -34.7 & +211 & +294 & -15.1 & -3.06 \\
\hline Relative $\mathrm{Mg}$ concentration & +2.78 & +1.34 & -22.2 & -15.6 & -5.00 & +20.6 \\
\hline Relative Mg content & -31.3 & -56.5 & +64.9 & +105 & -11.7 & -9.72 \\
\hline
\end{tabular}

vealed increases in foliar $\mathrm{N}$ and $\mathrm{Ca}$ of jack pine in year 3 under ash treatments, but ANOVAs did not meet the condition of homogeneity of variance and the significance threshold of $P<0.02$. No significant change in foliar macronutrients due to ash application was observed for white spruce.

Mean changes in total needle mass and nutrient content following ash application 


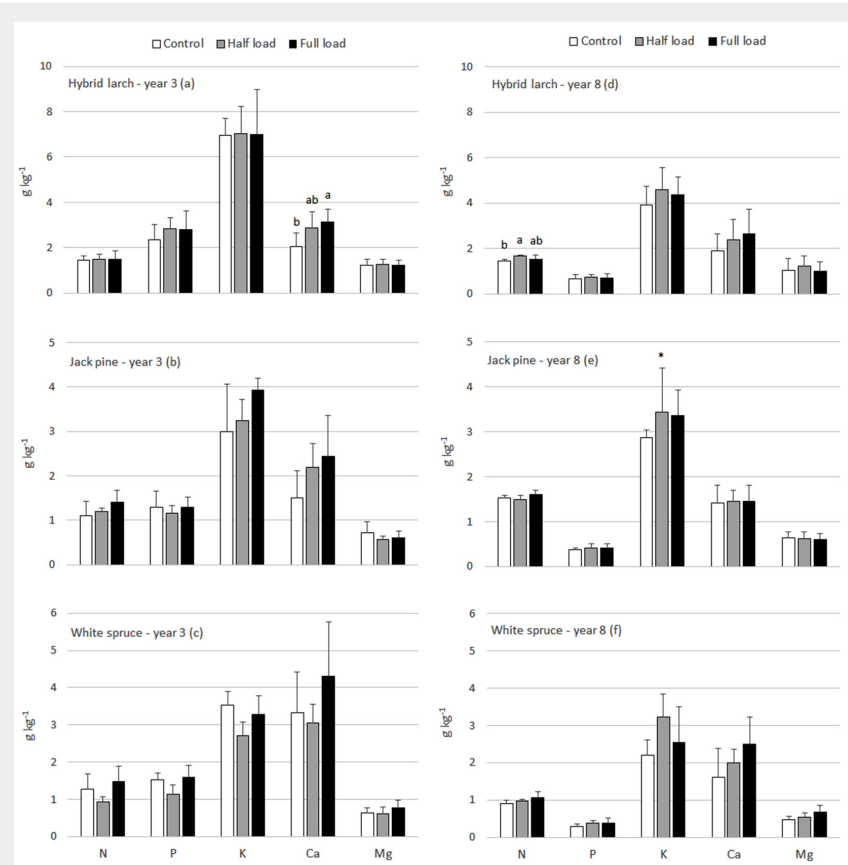

Fig. 3 - Hybrid larch (a,d), jack pine (b,e) and white spruce $(c, f)$ foliar $\mathrm{N}, \mathrm{P}, \mathrm{K}, \mathrm{Ca}$ and $\mathrm{Mg}$ response to ash treatments in years 3 and 8 . Means with standard deviations are presented. Different letters represent generalized significant differences between treatments within sampled years that were detected using the Tukey's HSD test. A significant interaction term (treatmentx site) is represented by the * symbol. In such cases, treatment differences between site were detected using simple main effects testing and for concision, outcomes are summarized in writing in the results section.
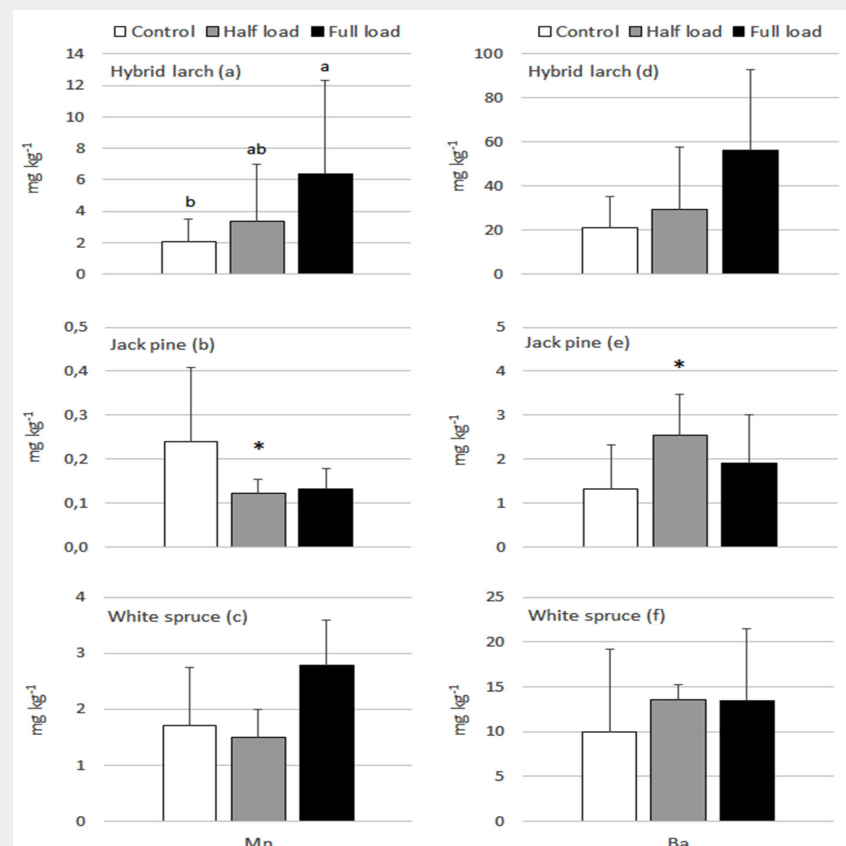

Fig. 4 - Hybrid larch (a,d), jack pine (b,e) and white spruce $(c, f)$ foliar $\mathrm{Mn}$ and $\mathrm{Ba}$ response to the ash treatments in year 8 . Means with standard deviations are presented. Different letters represent generalized significant differences between treatments within sampled years that were detected using the Tukey's HSD test. A significant interaction term (treatmentx site) is represented by the * symbol. In such cases, treatment differences between site were detected using simple main effects testing and for concision, outcomes are summarized in writing in the results section. (relative to control) were large to very large for jack pine, i.e., ranging from $+64.9 \%$ to $+211 \%$ for the half load and $+105 \%$ to $+295 \%$ for the full load (Tab. 3). Changes in needle mass and nutrient content for white spruce were relatively small, ranging from $-3.06 \%$ to $-32.9 \%$. Changes in needle mass and nutrient content for hybrid larch were also negative - they were relatively small for the half load $(-6.66 \%$ to $-33.2 \%)$ but larger for the full load (-34.7\% to $-57.1 \%)$.

A few significant differences between treatments were detected in regard to foliar Mn and Ba in year 8 (Fig. 4). First, the full load had significantly higher foliar $\mathrm{Mn}$ than the control in hybrid larch. There was also an increase in foliar $\mathrm{Ba}$ of hybrid larch in year 8 under the full load, but the ANOVAs did not meet the condition of homogeneity of variance nor the significance threshold of $P<0.02$. The interaction terms

Tab. 4 - Forest floor chemical properties (means with standard deviations in parentheses) as a function of ash treatment in years 3 and $8 . \mathrm{pH}$ is in a $\mathrm{CaCl}_{2}$ solution. $\mathrm{N}_{\mathrm{kjel}}$ is Kjeldahl nitrogen. $\mathrm{P}_{\text {Bray }}$ is Bray 2 phosphorus. $\mathrm{Ca}_{\mathrm{e}}, \mathrm{Mg}_{\mathrm{e}}, \mathrm{K}_{\mathrm{e}}, \mathrm{Na}_{\mathrm{e}}$ and Acidity are respectively exchangeable calcium, magnesium, potassium, sodium and acidity measured from a $\mathrm{NH}_{4} \mathrm{Cl}_{-} \mathrm{BaCl}_{2}$ extraction (Amacher et al. 1990), and $\mathrm{CEC}_{\mathrm{e}}$ and $\mathrm{BS}$ are effective cation exchange capacity and base saturation, both calculated from the $\mathrm{NH}_{4} \mathrm{Cl}_{-}-\mathrm{BaCl}_{2}$ extraction. See "Materials and methods" section for details on analyses. Different letters represent generalized significant differences between treatments within sampled years that were detected using the Tukey's HSD test. A significant interaction term (treatment×site) is represented by the * symbol. In such cases, treatment differences within each site were detected using simple main effects testing and for concision, outcomes are summarized in writing in the results section.

\begin{tabular}{|c|c|c|c|c|c|c|}
\hline \multirow{2}{*}{ Treatment } & \multicolumn{3}{|l|}{ Year 3} & \multicolumn{3}{|l|}{ Year 8} \\
\hline & Control & Half load & Full load & Control & Half load & Full load \\
\hline $\mathrm{pH}$ & $2.99 \pm 0.13^{c}$ & $3.50 \pm 0.24^{b}$ & $3.79 \pm 0.42^{a}$ & $2.91 \pm 0.17^{*}$ & $3.10 \pm 0.23^{*}$ & $3.35 \pm 0.38^{*}$ \\
\hline$N_{\text {kjel }}(\%)$ & $0.79 \pm 0.14$ & $0.67 \pm 0.16$ & $0.75 \pm 0.12$ & $0.88 \pm 0.20^{a}$ & $0.69 \pm 0.18^{b}$ & $0.72 \pm 0.24^{\mathrm{ab}}$ \\
\hline $\mathrm{P}_{\text {bray }}(\%)$ & $76.60 \pm 14.4^{b}$ & $80.90 \pm 20.1^{b}$ & $106.00 \pm 23.9^{a}$ & $34.90 \pm 15.3$ & $36.10 \pm 10.3$ & $59.50 \pm 54.3$ \\
\hline $\mathrm{Ca}_{\mathrm{e}}\left(\mathrm{cmol}_{\mathrm{c}} \mathrm{kg}^{-1}\right)$ & $8.28 \pm 2.09^{c}$ & $13.40 \pm 5.11^{b}$ & $20.60 \pm 6.86^{a}$ & $8.80 \pm 3.87$ & $8.69 \pm 3.01$ & $12.30 \pm 5.84$ \\
\hline $\mathrm{Mg}_{\mathrm{e}}\left(\mathrm{cmol}_{\mathrm{c}} \mathrm{kg}^{-1}\right)$ & $2.09 \pm 0.39^{b}$ & $2.12 \pm 0.53^{b}$ & $2.86 \pm 0.57^{a}$ & $1.80 \pm 0.68$ & $1.29 \pm 0.44$ & $1.74 \pm 0.77$ \\
\hline $\mathrm{K}_{\mathrm{e}}\left(\mathrm{cmol}_{\mathrm{c}} \mathrm{kg}^{-1}\right)$ & $1.12 \pm 0.36^{b}$ & $1.22 \pm 0.40 \mathrm{ab}$ & $1.24 \pm 0.50^{\mathrm{a}}$ & $0.86 \pm 0.30^{a}$ & $0.48 \pm 0.21^{b}$ & $0.49 \pm 0.13^{b}$ \\
\hline $\mathrm{Na}_{\mathrm{e}}\left(\mathrm{cmol}_{\mathrm{c}} \mathrm{kg}^{-1}\right)$ & $0.30 \pm 0.08^{b}$ & $0.41 \pm 0.17 \mathrm{ab}$ & $0.45 \pm 0.14^{\mathrm{a}}$ & $0.17 \pm 0.12^{a}$ & $0.05 \pm 0.02^{c}$ & $0.07 \pm 0.02^{b}$ \\
\hline Acidity $_{\mathrm{e}}\left(\mathrm{cmol}_{\mathrm{c}} \mathrm{kg}^{-1}\right)$ & $10.10 \pm 2.10^{\mathrm{a}}$ & $6.08 \pm 1.84^{b}$ & $5.13 \pm 2.66^{b}$ & $11.60 \pm 3.12^{*}$ & $7.96 \pm 2.30^{*}$ & $6.67 \pm 3.08^{*}$ \\
\hline CEC $\left(\mathrm{cmol}_{\mathrm{c}} \mathrm{kg}^{-1}\right)$ & $21.90 \pm 2.52^{b}$ & $23.2 \pm 5.46^{b}$ & $29.50 \pm 5.47^{\mathrm{a}}$ & $23.20 \pm 4.95^{\mathrm{a}}$ & $18.50 \pm 4.26^{b}$ & $21.30 \pm 6.55^{\mathrm{ab}}$ \\
\hline BS (\%) & $53.80 \pm 7.99^{c}$ & $70.0 \pm 9.29^{b}$ & $80.70 \pm 12.0^{a}$ & $49.60 \pm 12.7^{*}$ & $55.80 \pm 10.5^{*}$ & $65.60 \pm 12.3^{*}$ \\
\hline
\end{tabular}


Tab. 5 - Manganese speciation (according to the sequential extraction method proposed by Warden \& Reisenauer 1991) in the forest floor (a) and mineral soil (b) in a subset of samples collected under the ash treatments in hybrid larch plots only. No statistical test was conducted on these data to compare ash treatments considering that only one sample per treatment per site was analyzed. See "Materials and methods" section for details on sequential extraction procedure.

\begin{tabular}{lrrrrcc}
\hline \multirow{2}{*}{ Mn forms } & \multicolumn{2}{c}{ Forest floor } & \multicolumn{3}{c}{ Mineral soil } \\
\cline { 2 - 7 } & \multicolumn{1}{c}{ Control } & \multicolumn{1}{c}{ Half load } & \multicolumn{1}{c}{ Full load } & \multicolumn{1}{c}{ Control } & Half load & Full load \\
\hline Readily soluble $\left(\mathrm{mg} \mathrm{kg}^{-1}\right)$ & $99.3 \pm 110$ & $123.0 \pm 58.4$ & $223.0 \pm 82.7$ & $0.67 \pm 0.44$ & $2.33 \pm 1.82$ & $1.17 \pm 0.59$ \\
\hline Weakly adsorbed $\left(\mathrm{mg} \mathrm{kg}^{-1}\right)$ & $13.4 \pm 24.3$ & $24.5 \pm 16.5$ & $51.7 \pm 25.0$ & $0.02 \pm 0.10$ & $0.00 \pm 0.18$ & $0.00 \pm 0.13$ \\
\hline Specifically adsorbed $\left(\mathrm{mg} \mathrm{kg}^{-1}\right)$ & $0.76 \pm 0.77$ & $4.34 \pm 2.72$ & $12.1 \pm 11.7$ & $0.12 \pm 0.16$ & $0.04 \pm 0.04$ & $0.13 \pm 0.21$ \\
\hline Oxide-bound $\left(\mathrm{mg} \mathrm{kg}^{-1}\right)$ & $1.15 \pm 0.94$ & $26.8 \pm 24.0$ & $95.8 \pm 89.8$ & $18.4 \pm 31.4$ & $0.33 \pm 0.25$ & $9.82 \pm 16.8$ \\
\hline Total $\left(\mathrm{mg} \mathrm{kg}^{-1}\right)$ & $115 \pm 136$ & $179.0 \pm 84.4$ & $383.0 \pm 191$ & $19.2 \pm 32.1$ & $2.54 \pm 1.96$ & $11.0 \pm 17.4$ \\
\hline
\end{tabular}

for $\mathrm{Mn}$ and $\mathrm{Ba}$ in jack pine were significant, thus leading to simple main effects testing within each site. There were significant differences in Pascalis 1 and Senneterre, although there was no consistent pattern in the results. As a whole, (i) foliar $\mathrm{Mn}$ and $\mathrm{Ba}$ levels were respectively higher and lower under the control than the half and full loads in Senneterre; and (ii) the full load exhibited significantly lower foliar Ba levels than the control and half load in Pascalis 1 (results not shown). No significant difference between treatments was observed for foliar $\mathrm{Mn}$ and $\mathrm{Ba}$ of white spruce.

\section{Soil chemical properties}

Forest floor chemical properties are displayed in Tab. 4 for years 3 and 8 . Overall, forest floor $\mathrm{pH}$, exchangeable $\mathrm{Ca}$ levels and base saturation significantly increased with increasing ash load in year 3 . In the case of extractable $\mathrm{P}$, exchangeable $\mathrm{Mg}$ and effective CEC, the full load had significantly higher values than the control and half load, whereas exchangeable $\mathrm{K}$ and $\mathrm{Na}$ levels under the full load were significantly higher than the control. Interaction terms were often significant for year 8 , which prompted for simple main effects testing to characterize ash treatment effects within each site. The effect of ash on the acidbase status of the forest floor was still significant in year 8 , but only at Senneterre in regard to $\mathrm{pH}$ and base saturation, and at Pascalis 2 and Senneterre in regard to exchangeable acidity. Exchangeable Ca levels in the forest floor under the full load were higher than the control and half load, but this was marginally significant $(P=0.08)$. The positive effect of the full load observed on forest floor effective CEC in year 3 was not detected in year 8 , and this was also the case for exchangeable $\mathrm{K}$ and $\mathrm{Na}$. Instead, the control generally showed significantly higher CEC, $K$ and Na values than the half and full loads. This pattern was also observed for forest floor $\mathrm{N}$.

The sequential $M n$ extraction results on soil samples collected under hybrid larch in year 8 are shown in Tab. 5. They reveal a consistent increase in Mn levels with increasing ash load for all forms in the forest floor. Manganese levels in the mineral soil were much lower than in the forest floor (i.e., readily available or oxide-bound forms) or at trace levels (i.e., weakly and specifically adsorbed forms). In the forest floor, Mn levels in the half and full loads increased, relative to the control, by respectively 1.24 - and 2.25 -fold for readily soluble Mn, 1.83- and 3.86-fold for weakly adsorbed $\mathrm{Mn}, 5.71$ - and 15.8 -fold for specifically adsorbed $\mathrm{Mn}, 23.2$ - and 83.0-fold for oxidebound $\mathrm{Mn}$, and 1.56- and 3.34-fold for total $\mathrm{Mn}$. In the mineral soil, there was no increase in Mn levels in the half and full loads relative to the control for weakly adsorbed, specifically adsorbed, oxide-bound and total $\mathrm{Mn}$, although readily available $\mathrm{Mn}$ increased respectively by 3.85- and 1.93 -fold. Exchangeable $\mathrm{Mn}$ extracted with the $\mathrm{NH}_{4} \mathrm{Cl}$ solution on forest floor samples collected in year 8 was higher under the half and full loads compared to the control (Tab. 6). This pattern was observed at all sites, but the difference was significant only at Senneterre (results not shown). There was no indication of a treatment effect on exchangeable Ba (Tab. 6).

The benefits of ash on the first $10 \mathrm{~cm}$ of mineral soil were also apparent in year 3, although perhaps not as statistically distinct as in the forest floor (Tab. S1 in Supplementary material). The positive effects were mostly observed at Pascalis 1 and Senneterre in year 3. Significant effects of ash on mineral soil had almost entirely disappeared in year 8 . The only exception is for exchangeable $\mathrm{Ca}$ for which the half load had significantly higher levels than the control, whereas the full load was not significantly different than the control due to a large standard deviation.

\section{Discussion}

The response of soil to ash application was mostly observed in the forest floor and this was fully expected (Tab. 4, Tab. S1 in Supplementary material). Chemical reactions responsible for such changes have been fully discussed by others (Augusto et al. 2008, Reid \& Watmough 2014, Brais et al. 2015). Reid \& Watmough (2014) suggested that soil acid-base indicators (e.g., $\mathrm{pH}$ and base saturation) tend to respond quickly to liming and ash application in the forest floor because (i) protons are readily buffered in contact with the carbonates to form bicarbonate ions, and (ii) base cations, namely $\mathrm{Ca}^{2+}$, are immediately available for the displacement of acidity adsorbed on the exchangeable complex (e.g., $\mathrm{H}^{+}$and $\mathrm{Al}^{3+}$ ). It takes longer for the ash to buffer the acidity in the mineral soil because the alkalinity from ash more slowly migrates to these depths. The alkalinizing effects of ash on soil can last for more than 15 years (Augusto et al. 2008, Saarsalmi et al. 2012). In our study, positive effects of ash on soils were more pronounced in year 3 than year 8. The short-term effects reported here may be due to the acidifying nature of the studied soils. These are boreal soils developed from felsic (acidic) Precambrian rocks in which acidification is a very strong driver of soil development. It is thus possible that the alkalinity brought about by the ash has faded away more quickly (relative to 15 years in other studies) due to the omnipresence of acidifying reactions in the soils. Our hypothesis that tree growth and survival would be increased by ash due to improved nutrient availability was only met for jack pine. On the one hand, there was a consistent positive increase in diameter and total height of jack pine with increasing ash loading at all three plantation sites in years 2 to 8 (Fig. 2 b, Fig. $2 d$ ). On the other hand, white spruce growth showed a

Tab. 6 - Forest floor exchangeable $\mathrm{Mn}$ and $\mathrm{Ba}$ (means with standard deviations in parentheses) extracted with a $\mathrm{NH}_{4} \mathrm{Cl}$ solution as a function of ash treatment in year 8 . A significant interaction term (treatment $\times$ site) is represented by the * symbol. In such cases, treatment differences within each site were detected using simple main effects testing and for concision, outcomes are summarized in writing in the results section.

\begin{tabular}{ccc}
\hline Treatment & Mn $\left(\mathrm{mmol}_{\mathrm{c}} \mathbf{~ k g}^{-1}\right)$ & $\mathrm{Ba}\left(\mathrm{mmol}_{\mathrm{c}} \mathbf{~ k g}^{-1}\right)$ \\
\hline Control & $1.63 \pm 1.07^{*}$ & $5.45 \pm 4.75$ \\
\hline Half load & $2.31 \pm 9.80^{*}$ & $3.46 \pm 2.57$ \\
\hline Full load & $3.43 \pm 2.43^{*}$ & $3.43 \pm 4.11$ \\
\hline
\end{tabular}


small positive response at only one of the two sites studied (i.e., Pascalis 2 - results not shown), whereas hybrid larch growth and survival were largely reduced under the full load at all sites (Fig. 2a, Fig. 2c). The contrasted responses in growth and survival reported here under similar growing conditions highlight the importance of identifying suitable species and application rates to maximize the benefits of wood ash amendments.

Our results are consistent with the findings of Emilson et al. (2020) in regard to jack pine and white spruce. This Canadawide study revealed that the relationship between short-term response of jack pine and application rates is relatively linear. Their study also suggested that white spruce and hybrid spruce ( $P$. engelmannii $x$ glauca) are not very responsive to ash ap plication. Our study also has important implications in regard to hybrid larch - it is a species that is sensitive to higher ash loads and its growth rates can be impaired with out proper application guidelines. In addition, hybrid larch was the only species studied that showed a negative response to ash application in regard to survival (Fig. 1a). To our knowledge, this is the first time that a negative response to wood ash is reported for Larix spp. and perhaps simila results can be expected for other larch species (e.g., tamarack, Larix laricina). Site selection also appears to be an importan factor to consider for wood ash amend ments of hybrid larch. While the half load had positive effects on growth at Pascalis 2 and Senneterre, it had adverse effects on mortality at Pascalis 1 and Senneterre as well as adverse effects on growth at Pas calis 1.

Jack pine is a pioneer species that has a high juvenile growth rate (Vasiliauskas \& Chen 2002). It is also known to be an opportunistic species in regard to nutrient ac quisition (Thiffault et al. 2006). In this respect, it benefited from the improved nutritional environment after ash application, as seen by the positive change in the soil acidbase status, effective cation exchange capacity, exchangeable $\mathrm{Ca}, \mathrm{Mg}$ and $\mathrm{K}$, and available P after three years (Tab. 4, Tab. S in Supplementary material). Positive effects of ash on jack pine needle mass and nutrient contents were clear (Tab. 3) but not as apparent for concentrations, although there were indications of improvements of $\mathrm{K}$ concentrations in year 8 and $\mathrm{K}$ and $\mathrm{Ca}$ concentrations in year 3 (Fig. $3 \mathrm{~b}$, Fig. 3e). One could also argue that wood ash may lead to additional benefits for jack pine plantations because mortality over 8 years of growth was reduced relative to the control. On average, mortality rate was $22 \%, 12 \%$ and $13.3 \%$ in the control, half load and full load, respectively (Fig. 1b). However, due to the high variability in the data, there was no statistical difference allowing for a robust inference on change following ash application. In addition, mortality rates of $12-13 \%$ for jack pine after 8 years of growth under ash treatment (Fig. 1b) are high compared to jack pine studies of similar length (Paquette et al. 2011). Jack pine is a common tree species in the Canadian boreal and is highly sought by the forest industry. Overall, jack pine plantations thus appear to be a suitable species for wood ash application on many sites and a general positive linear response is expected. However, no growth improvement of mature jack pine plantations located in the same region came from ash application (Brais et al. 2015), suggesting that benefits could be limited to the earlier stages of growth.

Early growth of white spruce remained lower than that of jack pine in our study. Jack pine and white spruce have contrasted growth patterns and nutrient acquisition strategies. Diaz et al. (2004) underlined a common trade-off between plant species with rapid acquisition of resources to plant species that use more conservative strategies and store nutrients in their tissues for longer periods. Jack pine falls closer to the first type, while white spruce falls closer to the second type. This can be deducted based on growth rates, but also on rooting patterns and needle longevity. The root system of jack pine is deeper than white spruce (Strong \& La Roi 1983) and needle longevity of jack pine (2-3 years Schoettle \& Fahey 1994) is shorter than that of white spruce ( $\sim 6$ years - Kayama et al. 2007). White spruce may not benefit as much as jack pine from the early improvement in forest floor chemical properties and nutrient availability/uptake (Tab. 3, Tab. 4, Fig. 3c, Fig. 3f) and in turn, this likely explains the inconsistent growth response to ash application (Fig. 2C, Fig. 2f).

A negative response to wood ash is not rare for Picea spp., especially black spruce which can be considered an even more conservative species than white spruce because of its slower growth and longer leaf longevity (about 8 years - Kayama et al. 2007). Brais et al. (2015) reported decreased growth of black spruce starting at 4 dry $\mathrm{Mg} \mathrm{ha}^{-1}$ (same ash as in our study). Emilson et al. (2020) also reported a general negative growth response of black spruce to ash application using the Canadian AshNet database, whereas Staples \& Van Rees (2001) and Bieser \& Thomas (2019) observed a negative response of white spruce to wood ash. Salt and metal toxicities were believed to be the cause for the decline in growth of black and white spruce. Similarly, mortality rate was increased in Picea spp. following ash application (Staples \& Van Rees 2001 for white spruce, Mandre et al. 2004 for Norway spruce). In our study on white spruce, mean mortality rate after 8 years varied between $14 \%$ and $17.3 \%$ and there was no indication of an effect of wood ash on mortality (only early effects, i.e., years 1 and 2, were observed - Fig. 1C). Measured mortality rate are also comparable to the literature on white spruce (Wang et al. 2000, Paquette et al. 2011). Therefore, we conclude that no overall improvement in survival was brought by the ash in our study.

Increases in available and precipitated (unavailable) forms of $\mathrm{Mn}$ in the soil under the ash treatments were observed (Tab. 5 , Tab. 6). This was particularly true in the forest floor at Senneterre where both the half and full loads had significantly higher exchangeable Mn levels than the control. The increase in available $\mathrm{Mn}$ appears to have led to high levels in hybrid larch needles (Fig. 4). After application of the same fly ash as our study at a rate of 8 dry $\mathrm{Mg} \mathrm{ha}^{-1}$, Brais et al. (2015) also observed an increase in exchangeable $\mathrm{Mn}$ of over $800 \%$ in the forest floor five years after the treatment. This application rate was larger than the full load used at Pascalis 1 and Pascalis 2 (5 dry Mg ha-1), but lower than the 14 dry Mg ha ${ }^{-1}$ at Senneterre.

Manganese is the micronutrient that ash often contains in the highest amount (as much as $10,000 \mathrm{mg} \mathrm{kg}^{-1}$ or $1 \%$ of the total weight - Swedish University of Agricultural Sciences, http://woodash.slu.se/eng/). In our study, Mn was at $0.73 \%$, which is higher than any other micronutrients in the fly ash (Fe was the second highest at $0.12 \%-T a b$. 1). While $\mathrm{Mn}$ is involved in photosynthesis and as a cofactor in enzymatic reactions in most plants (Marschner 2012), excessive $\mathrm{Mn}$ has been linked to reduced enzyme, hormone and chlorophyll production, inhibition of ATP formation, and reduced respiration (Elamin \& Wilcox 1986). The degree of tolerance of plants to $\mathrm{Mn}$ largely varies with genetic diversity within and among plant species (Simon et al. 1986) as well as the ability of other nutrients to reduce $\mathrm{Mn}$ uptake and transport to plant stems and leaves (Goss \& Carvalho 1992).

Manganese levels in hybrid larch needles were generally the highest, followed by white spruce and then jack pine. Eight years after ash application, the increase in $\mathrm{Mn}$ in hybrid larch needles was the largest (significant) and most linear of all nutrients, being, on average, 205, 337 and 633 $\mathrm{mg} \mathrm{Mn} \mathrm{kg-1}$ in the control, half load and full load, respectively (Fig. 4). Some trees under the full load at Senneterre reached values as high as $1500 \mathrm{mg} \mathrm{Mn} \mathrm{kg}^{-1}$ (results not shown). Schweitzer et al. (1999) demonstrated growth decreases due to Mn toxicities in Japanese larch (Larix leptolepis) seedlings in the greenhouse. In this respect, it is suspected that the high bioavailability of $\mathrm{Mn}$ associated with the full load of fly ash was detrimental to hybrid larch growth and survival. Mortality rate under the full load (average of $59.3 \%$ in year 8 , Fig. 1a) is well above measured mortality for 7-year-old hybrid larch plantations in Pennsylvania, USA (Zaczek et al. 1994). The high sensitivity of hybrid larch to Mn could be explained by the fact that it is a pioneer, fast growing and deciduous coniferous species (Gower \& Richards 1990), placing it as one of the most acquisitive (nutrients) species among conifers. The full nature and strength of the relationship between nee- 
dle Mn levels and hybrid larch growth and survival cannot be verified precisely with the experimental design. Our results sug gest that hybrid larch is more sensitive to a high activity of $\mathrm{Mn}$ in the forest floor compared to white spruce and jack pine, and that this adverse effect on larch can be observed on various sites and at relatively low application rates (i.e., half load of 2.5 dry $\mathrm{Mg} \mathrm{ha}{ }^{-1}$ at Pascalis 1). It is intriguing that the half load led to both detrimental (Pascalis 1, Senneterre) and positive effects (Pascalis 2 and Senneterre) on growth and survival of hybrid larch. This could be due to multiple factors controlling Mn bioavailability at the sites such as bedrock geochemistry, weathering rates, soil $\mathrm{pH}$, soil sorption properties $\left(\mathrm{CEC}_{\mathrm{e}}\right.$, nature of colloids), and activity of ligands in the soil solution such as organic acids and the hydroxide ion (Rieuwerts et al. 1998). Data from the sequential extraction are limited, but results consistently show that Pascalis 1 is the site with the highest background levels of available $M n$ in the soil, notably in the forest floor (225 mg kg-1 of readily soluble $M n$ ). In this respect, we speculate that detrimental effects of $M n$ in ash on hybrid larch growth and survival at Pascalis 1 were more likely to occur than at other sites and at lower application rates (i.e., half load). The half load at Senneterre was equivalent to 7 dry $\mathrm{Mg} \mathrm{ha}^{-1}$, but the site exhibited the lowest background levels of available $\mathrm{Mn}$ in soil $\left(19.2 \mathrm{mg} \mathrm{kg}^{-1}\right.$ of readily soluble $\mathrm{Mn}$ in the forest floor). In turn, this likely explains the overall benefits of this specific treatment on hybrid larch growth (but not survival) at the site. Our findings are important as hybrid larch is growing in popularity in the US and Canada (Townsend 2018) and thus, growers could be tempted to use wood ash as a soil amendment for hybrid larch plantations.

A common recommendation is an application rate not exceeding 10 dry $\mathrm{Mg} \mathrm{ha}^{-1}$ (Hannam et al. 2016). Jack pine responded positively to 14 dry $\mathrm{Mg} \mathrm{ha}^{-1}$ at Senneterre, whereas white spruce received a maximum rate of 5 dry $\mathrm{Mg}$ ha $^{-1}$ (only Pascalis 1 and Pascalis 2 included white spruce) and this also resulted in a positive growth response at Pascalis 2. However, metal toxicity is likely to occur at higher ash application rates for these species as well and in turn, positive responses are not expected to hold at much higher application rates. Critical thresholds are, however, difficult to establish with our study design and data.

Barium content in the fly ash used in our study was high ( 1500 $\mu \mathrm{g} \mathrm{g}^{-1}-$ Tab. 1). Barium is not a plant nutrient and very few toxicity studies have been conducted on $\mathrm{Ba}$ (Llugany et al. 2000, Lamb et al. 2013). These studies indicate that the direct toxicity of $\mathrm{Ba}$ to plants is relatively low, but $\mathrm{Ba}$ can potentially create nutrient imbalances by interfering with $\mathrm{Ca}$ and $\mathrm{Mg}$ uptake and even K uptake (Llugany et al. 2000, Suwa et al. 2008). Notably, K uptake can be supressed by $\mathrm{Ba}^{2+}$ as the latter is a membrane channel inhibitor (Suwa et al. 2008). Thus, large additions of $\mathrm{Ba}$ in the soil via ash addition could adversely impact tree growth by lowering the uptake of these nutrients. The mobility of Ba will depend on the compounds it forms in the soil environment. In ash-amended acid forest soils, Ba is likely to form Ba sulfate and carbonate, which do not dissolve well in water and thus form stable precipitates in the soil. Acidic boreal soils should therefore act as a sink for any addition of Ba from ash and ash disposal should not be a health concern for terrestrial and aquatic ecosystems, at least in the short term. This seems to be supported by our data on soil Ba (Tab. 6). On average, forest floor under the control exhibited higher levels of $\mathrm{Ba}$ than the half and full loads, but the high variability in the data has masked any statistical differences. Conversely, a tendency for higher Ba levels in needles under the half and full loads compared to the control were observed for the more acquisitive species, i.e., hybrid larch and jack pine, but differences were not statistically significant for the most part (Fig. 4d, Fig. 4e). Nevertheless, monitoring of foliar chemistry should be encouraged in future studies to confirm that the uptake of essential nutrients is not being interfered by a non-nutrient element with similar chemical features in terms of radii and valences (e.g., Ba and Sr vs. Ca, Rb vs. K).

Understanding how wood ash application leads to a decline in tree growth is of significant importance if this is to become a common practice for reforestation efforts in the Canadian boreal, but this is a difficult undertaking because several factors are likely involved. For example, Reid \& Watmough (2014) suggested that the time since ash application can be an important factor to explain the amplitude of tree growth response. Similarly, the data in our study showed a lag in the response of tree species, whether positive or negative (Fig. 2 ). It took only one and two years to observe a significant response of hybrid larch (mortality) and jack pine (growth), respectively. In regards to white spruce, the first significant response was observed at year 8 , although a significant response could have occurred between years 4 and 7 but those years were unmeasured. This lag could be associated to the time required for nutrients from the ash to transfer to and react with the soil and eventually be absorbed by tree roots (Reid \& Watmough 2014). Shepard (1997) also argued that plant competition can be favored following ash application and that this can be problematic for the early growth of some tree species. Finally, tree response to ash application can be impacted by several other factors such as soil physico-chemical and microbial compositions (e.g., texture, forest floor depth, acid-base status, mycorrhizae - Liiri et al. 2007, Reid \& Watmough 2014), and stand development stage (age) and nutrient demand (Brais et al. 2015).

\section{Conclusions}

The largest wood volume in the Canadian boreal comes from Picea spp. (NRC 2018). However, considering the physiological traits of the genera and based on the general results in our study and elsewhere, it can be concluded that the benefits of applying ash in white spruce stands are more likely to come from reduced disposal costs in landfills than increased tree growth per se. The benefits are forecasted to be larger in the case of jack pine stands and are potentially larger for hybrid larch stands as well, but our findings suggest a high risk for a negative response of larch if ash application rates are too high. Yet, the operational nature of the experimental design (i.e., large plots and high variability) did not allow to determine proper application rates for hybrid larch nor to identify the exact mechanisms that lead to this negative response (e.g., Mn toxicity). To do so, more refined studies are required. This means that experimental designs must encompass more gradual ash loads (e.g., o, 2, 4, 8, 12,16 dry $\mathrm{Mg} \mathrm{ha}^{-1}$ ) under an array of soil conditions, and trees must be monitored annually not just for growth and foliar nutrition but mortality as well.

\section{Acknowledgments}

This work was supported by the Natural Sciences and Engineering Research Council of Canada (NSERC RDCPG, Grant 45041213), Resolute Forest Products, and Domtar Forest Products, and the Quebec Ministry of Forests, Wildlife and Parks. We are grateful to Resolute, the city of Senneterre and Boralex for their help implementing the experiment, A. Coulomb, H. Brais-Harvey, J. Therrien, E. Robert, S. Rollin, J. Frennette and employees of Kinojevis-Abijevis Forest Coop for field assistance, and A. Brousseau, H. Lalande, J. Ricard-Piché, R. Mincheva and $O$. Bélanger for laboratory work.

\section{References}

Alam S, Kodama R, Akiha F, Kamei S, Kawai S (2007). Alleviation of manganese phytotoxicity in barley with calcium. Journal of Plant Nutrition 29: 59-74. - doi: 10.1080/01904160500416 463

Amacher M, Henderson R, Breithaupt M, Seale C, LaBauv J (1990). Unbuffered and buffered salt methods for exchangeable cations and effective cation exchange capacity. Soil Science Society of America Journal 54: 1036-1042. - doi: 10.2136/sssaj1990.03615995005400040018x

Augusto L, Bakker MR, Meredieu C (2008). Wood ash applications to temperate forest ecosystems - Potential benefits and drawbacks. Plant and Soil 306: 181-198. - doi: 10.1007/s11104008-9570-z

Bélanger N, Paré D, Hendershot W (2007). Determining nutrient availability in forest soils. In: "Soil Sampling and Methods of Analysis - $2^{\text {nd }}$ edn" (Carter M, Gregorich EG eds). CRC Press, Boca Raton, FL, USA, pp. 317-330.

Bieser JMH, Thomas SC (2019). Biochar and highcarbon wood ash effects on soil and vegetation 
in a boreal clearcut. Canadian Journal of Forest Research 49: 1124-1134. - doi: 10.1139/cjfr-20190039

Brais S, Bélanger N, Guillemette T (2015). Wood ash and $\mathrm{N}$ fertilization in the Canadian boreal forest: Soil properties and response of jack pine and black spruce. Forest Ecology and Management 348: 1-14. - doi: 10.1016/j.foreco.2015. 03.021

CRAAQ (2013). Guide de référence en fertilisation [Fertilization reference guide] ( $2^{\text {nd }}$ edn). Centre de Référence en Agriculture et Agroalimentaire du Québec - CRAAQ, Québec, Canada, pp. 479. [in French]

Diaz S, Hodgson JG, Thompson K, Cabido M, Cornelissen JHC, Jalili A, Montserrat-Martí G, Grime JP, Zarrinkamar F, Asri Y, Band SR, Basconcelo S, Castro-Díez P, Funes G, Hamzehee B, Khoshnevi $M$, Pérez-HarguindeguyN, Pérez-Rontomé MC, Shirvany FA, Vendramini F, Yazdani S, Abbas-Azimi R, Bogaard A, Boustani S, Charles $M$, Dehghan $M$, De Torres-EspunyL, Falczuk V, Guerrero-CampoJ, Hynd A, Jones G, Kowsary E, Kazemi-Saeed F, Maestro-MartínezM, RomoDíez A, Shaw S, Siavash B, Villar-Salvador P, Zak MR (2004). The plant traits that drive ecosystems: evidence from three continents. Journal of Vegetation Science 15: 295-304. - doi: 10.165 8/1100-9233(2004)015[0295:TPTTDE]2.0.CO;2

Elamin OM, Wilcox GE (1986). Manganese toxicity in watermelon plants as influenced by nitrogen form. Journal of the American Society of Horticulture Science 111: 765-768. [online] URL: http://pascal-francis.inist.fr/vibad/index.php?act ion=getRecordDetail\&idt=8146757

Emilson CE, Hannam K, Aubin I, Basiliko N, Bélanger $\mathrm{N}$, Brais S, Diochon A, Fleming R, Jones $T$, Kabzems R, Laganière J, Markham J, Morris D, Rutherford M, Van Rees K, Venier LA, Webster K, Hazlett P (2018). Synthesis of current AshNet study designs and methods with recommendations towards a standardized protocol. Information Report GLC-X-22, Natural Resources Canada, Canadian Forest Service, Great Lakes Forestry Centre, Sault Ste. Marie, Canada, pp. 39. [online] URL: http://www.researchgate.net/ publication/328744185

Emilson CE, Bélanger N, Brais S, Chisholm CE, Diochon A, Joseph R, Markham J, Morris D, Van Rees K, Rutherford M, Venier LA, Hazlett PW (2020). Short-term growth response of jack pine and spruce spp. to wood ash amendment across Canada. Global Change Biology - Bioenergy 12: 158-167. - doi: 10.1111/gcbb.12661

Expert Committee on Soil Survey (1998). The Canadian system of soil classification ( $3^{\text {rd }}$ edn). Publication no. 1646, Agriculture Canada, NRC Research Press, Ottawa, Canada, pp. 187. [online] URL: http://books.google.com/books?id=4 aHVg18eDLYC

Goss MJ, Carvalho MJ (1992). Manganese toxicity: the significance of magnesium for the sensitivity of wheat plants. Plant and Soil 139: 91-98. - doi: 10.1007/BFoo012846

Gower ST, Richards JH (1990). Larches: deciduous conifers in an evergreen world. BioScience 40: 818-826. - doi: 10.2307/1311484

Hannam KD, Deschamps C, Kwiaton M, Venier L, Hazlett PW (2016). Regulations and guidelines for use of wood ash as soil amendment in Canadian forests. Information Report GLC-X-17, Ca- nadian Forest Service, Natural Resources Canada, Great Lakes Forestry Centre, Sault Ste. Marie, Canada, pp. 46. [online] URL: http://oa resource.library.carleton.ca/wcl/2017/20170126/ Fo123-2-17-2016-eng.pdf

Hébert M (2015). Guide sur le recyclage des matières résiduelles fertilisantes: critères de référence et normes réglementaires [Guide to recycling fertilizing residual materials: benchmarks and regulatory standards] (edn 2015). Gouvernement du Québec, Québec, Canada, pp. 216. [in French]

Kayama M, Kitaoka S, Wang W, Choi D, Koike T (2007). Needle longevity, photosynthetic rate and nitrogen concentration of eight spruce taxa planted in northern Japan. Tree Physiology 27: 1585-1593. - doi: 10.1093/treephys/27.11. 1585

Kashem MDA, Kawai S (2007). Alleviation of cadmium phytotoxicity by magnesium in Japanese mustard spinach. Soil Science and Plant Nutrition 53: 246-251. - doi: 10.1111/j.1747-0765.2007. 00129.x

Lamb DT, Matanitobua VP, Palanisami T, Megharaj M, Naidu R (2013). Bioavailability of barium in plants and invertebrates in soils contaminated by barite. Environmental Science and Technology 47: 4670-4676. - doi: 10.1021/es3020 53d

Liiri M, Ilmarinen K, Setala H (2007). Variable impacts of enchytraeid worms and ectomycorrhizal fungi on plant growth in raw humus soil treated with wood ash. Applied Soil Ecology 35: 174-183. - doi: 10.1016/j.apsoil.2006.04.005

Llugany M, Poschenrider C, Barcelo J (2000). Assessment of barium toxicity in bush beans. Archives of Environmental Contamination and Toxicology 39 (4): 440-444. - doi: $10.1007 / \mathrm{so02}$ 440010125

Lundborg A (1998). A sustainable forest fuel system in Sweden. Biomass and Bioenergy 15 (45): 399-406. - doi: 10.1016/So961-9534(98)0004 6-4

Mandre M, Korsjukov R, Ots K (2004). Effect of wood ash application on the biomass distribution and physiological state of Norway spruce seedlings on sandy soils. Plant and Soil 265: 301314. - doi: 10.1007/s11104-005-0509-3

Marschner H (2012). Marschner's mineral nutrition of higher plants ( $3^{\text {rd }}$ edn). Academic Press, London, UK, pp. 672.

McKeague JA (1978). Manual on soil sampling and methods of analysis ( $2^{\text {nd }}$ edn). Canadian Society of Soil Science, Ottawa, Canada, pp. 179.

NRC (2018). The state of Canada's forests. Annual report 2018. Natural Resources Canada NRC, Canadian Forest Service, Ottawa, Canada, pp. 76.

Paquette A, Girard J-P, Walsh D (2011). Deep planting has no short- or long-term effect on the survival and growth of white spruce, black spruce, and jack pine. Northern Journal of Applied Forestry 28: 146-151. - doi: 10.1093/njaf/28. 3.146

Régnière J (1996). Generalized approach to landscape-wide seasonal forecasting with temperature-driven simulation model. Environmental Entomology 25: 869-881. - doi: 10.1093/ee/25.5. 869

Reid C, Watmough SA (2014). Evaluating the effects of liming and wood-ash treatment on for- est ecosystems through systematic meta-analysis. Canadian Journal of Forest Research 44: 867-885. - doi: 10.1139/cjfr-2013-0488

Rieuwerts JS, Thornton I, Farago ME, Ashmore MR (1998). Factors influencing metal bioavailability in soils: preliminary investigations for the development of a critical loads approach for metals. Chemical Speciation and Bioavailability 10: 61-75. - doi: 10.3184/095422998782775835

Saarsalmi A, Smolander A, Kukkola M, Moilanen M, Saramäki J (2012). 30-year effects of wood ash and nitrogen fertilization on soil chemical properties, soil microbial processes and stand growth in a Scots pine stand. Forest Ecology and Management 278: 63-70. - doi: 10.1016/j.for eco.2012.05.006

Saucier J-P, Grondin P, Robitaille A, Bergeron J-F (1998). Zones de végétation et domaines bioclimatiques du Québec [Vegetation zones and bioclimatic domains of Quebec] ( $3^{\text {rd }}$ edn). Ministère des Ressources Naturelles, de la Faune et des Parcs, Québec, Canada. [map - in French] Schoettle AW, Fahey TJ (1994). Foliage and fine root longevity of pines. Ecological Bulletins 43: 136-153. [online] URL: http://www.jstor.org/sta ble/20113137

Schweitzer CJ, Sharpe WE, Edwards PJ (1999). The effect of soil manganese on Japanese larch (Larix leptolepis Sieb. and Zucc.) seedlings in the greenhouse. In: Proceedings of the " $12^{\text {th }}$ Central Hardwood Forest Conference". General Techical Report SRS-24, USDA Forest Service, Southern Research Station, Asheville, USA, pp. 293. [online] URL: http://www.fs.usda.gov/tree search/pubs/1510

Shepard RK (1997). Response of young black spruce (Picea mariana (Mill.) B.S.P.) to a mixture of wood ash and secondary paper mill sludge. Miscellaneous Report No. 405, Maine Agricultural and Forest Experiment Station, Maine, USA, pp. 13. [online] URL: http://digi talcommons.library.umaine.edu/aes_miscrepor ts/22/

Simon JE, Wilcox GE, Simini M, Elamin O, Decoteau DR (1986). Identification of manganese toxicity and magnesium deficiency on melons grown in low-pH soils. HortScience 21: 13831386. [online] URL: http://www.personal.psu. edu/drd10/Site/Publications_files/MnMgMelon. pdf

Staples TE, Van Rees KCJ (2001). Wood/sludge ash effects on white spruce seedling growth. Canadian Journal of Soil Science 81: 85-92. - doi: 10.4141/So0-014

Strong WL, La Roi GH (1983). Root-system morphology of common boreal forest trees in Alberta, Canada. Canadian Journal of Forest Research 13: 1164-1173. - doi: 10.1139/×83-155

Suwa R, Jayachandra K, Nguyen NT, Boulenouar A, Fujita K, Saneoka H (2008). Barium toxicity effects in soybean plants. Archives of Environmental Contamination and Toxicology 55: 397403. - doi: 10.1007/s00244-008-9132-7

Thiffault E, Paré $D$, Bélanger $N$, Munson A, Marquis $F$ (2006). Harvesting intensity at clear-felling in the boreal forest: impact on soil and foliar nutrient status. Soil Science Society of America Journal 70: 691-701. - doi: 10.2136/sssaj 2005.0155

Timmer VR (1997). Exponential nutrient loading: a new fertilization technique to improve seed- 
ling performance on competitive sites. New Forests 13 (1-3): 279-299. - doi: 10.1023/A:100650 2830067

Townsend E (2018). Is hybrid larch the future of the northern forest? The Northern Logger 12: 10-16.

Varnagiryte-Kabašinskiene I (2012). Toward the rational use of forest biomass: Lithuanian case study. Journal of Forest Science 58: 465-471. doi: 10.17221/10/2012-JFS

Vasiliauskas S, Chen HYH (2002). How long do trees take to reach breast height after fire in northeastern Ontario? Canadian Journal of Forest Research 32: 1889-1892. - doi: 10.1139/xo2104
Wang GG, Siemens JA, Keenan V, Philippot D (2000). Survival and growth response of black and white spruce seedlings in relation to stock type, site preparation and plantation type in southeastern Manitoba. The Forestry Chronicle 76: 775-782. - doi: 10.5558/tfc76775-5

Warden BT, Reisenauer HM (1991). Fractionation of soil manganese forms important to plant availability. Soil Science Society of America Journal 55: 345-349. - doi: 10.2136/sssaj1991.036 $15995005500020007 x$

Zaczek JJ, Steiner KC, Shipman RD (1994). Performance of Japanese and hybrid larch progenies in Pennsylvania. Northern Journal of Applied Forestry 11: 53-57. - doi: 10.1093/njaf/11.2.53
Ziadi N, Sen Tran T (2008). Mehlich 3 - Extractable elements. In: "Soil Sampling and Methods of Analysis - $2^{\text {nd }}$ edn" (Carter MR, Gregorich EG, eds.). CRC Press, Boca Raton, FL, USA, pp. 81-88.

\section{Supplementary Material}

Tab. S1 - Mineral soil $(0-10 \mathrm{~cm})$ chemical properties as a function of ash treatment in years 3 and 8 .

Link: Belanger_3597@supplo01.pdf 